ESSAY

\title{
Goodbye to Managing Editor Lynn Heasley
}

\section{Phil Wankat and Rich Felder}

$\mathrm{L}$ ynn Heasley started with $C E E$ in the spring of 2005. Before coming to $C E E$ she had been an independent contractor doing copy editing for American Automobile Association (AAA) Guide Books. When Carole Yocum retired, Lynn became the managing editor of $C E E$, beginning with the Summer 2005 issue. She resigned in January 2019 to return to independent contracting and have time for other pursuits. Her last issue as managing editor was Winter 2019.

Both authors of this tribute have had the privilege and pleasure of working with Lynn in her nearly 14 years of dedicated service to chemical engineering education and Chemical Engineering Education-Phil Wankat as associate editor and editor of the journal and Rich Felder as author of the Random Thoughts columns that appeared in every issue until Winter 2017.

\section{The Editor's Recollections (PW)}

Since there are no equations in AAA guide books, one of Lynn's first tasks was learning how to typeset equations. Although she did not realize it at the time, learning on her own how to do unfamiliar tasks with essentially no supervision would be the story of her tenure at $C E E$. From start to finish, she had a remarkable record of accuracy and punctuality. Despite slow reviewers, authors who took forever to do revisions, editors who lost manuscripts (very rare), new publishing technology, computer glitches, hurricanes, illness, and death in her family, every one of the 55 issues she managed was delivered on time.

When new submissions arrived, Lynn first sent a note to authors that their manuscript had been received, and she then used keywords to determine the appropriate member of the editorial staff and sent the manuscript to him or her. After the editor had selected reviewers, Lynn sent copies of the manuscript to the reviewers with due dates for the reviews, reminded them as the due dates approached, notified them that their reviews were late and reminded them of their lateness with increasing frequency, and eventually collected the reviews. Once enough reviews were available, Lynn sent them to the journal editor for a decision, and if a response did not appear reasonably quickly, she sent reminders to the editor. If revisions of a manuscript were needed (as they were $99 \%$ of the time), Lynn requested them from the authors, and when the revised manuscript arrived she conveyed it to the editor and again sent reminders that a decision was needed. After a manuscript was accepted, she obtained a final copy from the authors, typeset it, proofread it and made any necessary corrections (few were generally needed-Lynn doesn't make many mistakes), and sent copies to the authors and an associate editor for additional proofreading. Once enough papers for an issue were typeset and proofread, she sent them to the printer. When the printer returned the galleys for the issue, Lynn proofread them and made necessary corrections, and the issue finally went to press.

If I ever needed someone to herd cats I would hire 
Lynn. At any given time she could be managing as many as a dozen manuscripts spread across the different stages of that process. It all worked like a Swiss clock because Lynn is super-organized, always knew where each paper stood, and somehow managed to keep everything on track.

When Lynn started at CEE, the journal was still transitioning from 20-century publishing technology to electronic publishing. She did not have an IT department to help manage the transition, so she had to learn all the ropes on her own. Sometimes an editor would point a direction in the electronic conversion, but editors never actually did the work. My first saved e-mail to her (July 29, 2005) asked if CEE had considered sending pdfs to proofreaders instead of using snail mail. The next set of proofs went out as pdfs. $C E E$ now has an electronic version of the journal and is using a computer management system because Lynn set those systems up.

During her tenure with $C E E$, Lynn worked with three different editors (Tim Anderson, Jennifer Curtis, and Phil Wankat); nine assistant, associate and section editors; four Publication Board chairs; and many authors. Lynn was always courteous, even with the rare rude author.

Dealing with authors, reviewers, editors and printers and typesetting and proofreading manuscripts was not all Lynn did. She also handled subscriptions and advertisements, collected money, did the accounting for $C E E$, and paid the bills. In the words of a popular song, "You don't know what you've got till it's gone." Chemical Engineering Education had an inkling of what it had, but now that Lynn has moved on we are very aware of what we have lost. And in the words of an old Gaelic blessing,

May the roads rise with Lynn,

And the winds be always at her back,

And may the Lord hold her in the hollow of his hand.

\section{The Author's Recollections ( $R F)$}

Four times a year, I'd get an email from Lynn letting me know that we were two weeks away from the deadline for my next column. I'm usually pretty good about meeting deadlines, and so I would get to work shortly after hearing from her and get my first draft done quickly. I'm also a bit perfectionistic about writing (hysterically obsessive, Rebecca would say, but what does she know?), and so I'd then start revising. Somewhere between one day and five minutes before the deadline I'd finish the 23rd draft (or whichever one I was up to), and believing that it was flawless, email it to Lynn. A day later-or on rare occasions two days later-I'd get the typeset manuscript to proofread. Once in a long while there was a typo in what Lynn sent that I'd correct, but invariably I'd go on to make a few (ok, many) changes in what I had previously sent her, wondering what gave me the crazy idea that what I had sent was acceptable, and ship them back to Lynn. Next day, a new typeset manuscript rolled in, with all of my requested changes in place and perfect. Most of the time I accepted that version, but often I found still more revisions to make and fired them back to Lynn. Copy editors are known for getting cranky about multiple revisions of supposedly completed manuscripts, but never Lynn - or if she ever got cranky, she concealed it perfectly. We played tag like that until either we reached the actual deadline or I got tired of looking at the column and declared it good to go.

In the 15 years I worked with Lynn, I never met her in person or saw her on a video conference call, and if I bumped into her on the street now I wouldn't have the faintest idea who she is. I just know that I've never had a professional colleague more competent and efficient than Lynn Heasley. Like Phil, if I had a clowder of cats to herd (look that word up if you doubt me) or any other challenging task to complete, I would unhesitatingly turn to her for help, confident that the job would be done within a day or, if it bordered on the impossible, two days.

Lynn set a standard for excellence that will be hard to maintain, no matter who succeeds her as managing editor. I retired as author of Random Thoughts in 2017, and I'm just as glad that Lynn's successor and I won't have to go through learning curves with each other. I wish Lynn good fortune and give my heartiest congratulations to whoever reaps the benefits of her excellence in her next venture. $\square$ 